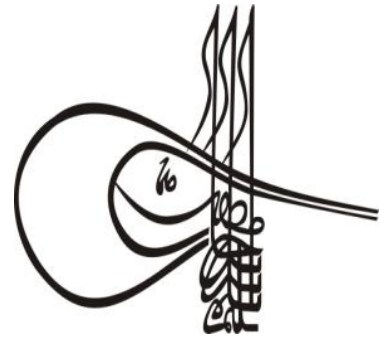

Received/Geliş: 18.07.2019

Go Report Dates/Rapor Tarihleri: Referee 1 (12.10.2019)-Referee 2 (09.10.2019)

\section{Turkígh Gtudies \\ Social Sciences}

Volume 14 Issue 5, 2019, p. 2565-2578

DOI: 10.29228/TurkishStudies. 24823

ISSN: 2667-5617

Skopje/MACEDONIA-Ankara/TURKEY

Research Article / Araştırma Makalesi

ArticleInfo/Makale Bilgisi

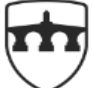

INTERNATIONAL BALKAN UNIVERSITY

EXCELLENCE FOR THE FUTURE IBU.EDU.MK

\Accepted/Kabul: 15.10 .2019

This article was checked by intihal.net.

\title{
ÇEVRE ETİĞİ: KEDİLR, SAMİ PAŞAZADE SEZAİ
}

\author{
Serpil TUNÇER*
}

\section{öz}

Sami Paşazade Sezai (1860-1936) tarihsel süreç olarak Osmanlı ve Cumhuriyet dönemlerine tanık olmuş önemli bir yazarımızdır. Sezai, ürettiği gerçekçi kısa öyküleriyle dönemin Batı edebiyatı tarzına yakın duruşuyla tanınmıştır. Kısa öykülerinde toplumsal günlük yaşama ait önemsenmese de insanları yaralayabilen, küçük sayılan sorunlara odaklanmıştır. Kediler (Cats, 1892) başlıklı kısa öyküsü de, insanın özel (mahrem) yaşamında sergilediği duruş fonunda, insan-hayvan ilişkisini, özellikle de insan - kedi ilişkisini irdelemektedir. Bu çalışmanın amacı çevre etiği alanında gelinen son noktayı ve çevre ile ilişkilerde geliştirilen davranış biçimlerini ortaya koyarak dünya üzerindeki yaşama ilișkin net ve açık bir bakış açısı oluşturulmasında ekoeleştiriye katkıda bulunabilmektir. Şu anda geçerli olan etik kodlar insanın Doğaya ve kendisi dişındaki tüm varlıklara karş1 tavrını nasıl yönlendirmektedirler? İnsanın öteki varlıklar karşısındaki üstünlük kompleksi ve egosundan vazgeçmesini sağlayabilecek bir etik kod düzenlenebilmesi geçekten insan yaşamının en temel ve en zorlu sorunudur ve postmodern etik yaklaşımın temel eleştirisi de modernizmin büyük bir yaşam projesi olmasına karşın tıkandığı noktalarda etik kodların eleştirisinden yola çıkmaktadır. Doğanın gücü ve anlamı konusunda, fiziksel ve ruhsal düzeyde insanın büyük bir önyargısı vardır. Doğaya, kültür karşısında konumlandırılarak hiyerarşik bir şekilde bölünme ve ikili karşıtlık ilişkisi içinde ötekileştirilme atfedilmektedir. Hatta, bu bölünme ve hiyerarşik düzen yalnızca Doğa ve kültür ikilisine atfedilmeyerek tüm sosyo-ekonomik düzenin oluşturulmasında temel alınarak gezegendeki tüm canlı türlerinin belli öncelikler, ayrımlar ve sıralamalara göre sınıflandırılmaları şeklinde uygulanmaktadır. Bu bağlamda, Doğa, insan için, ancak parçalanmış, altüst olmuş, marjinal kültürel-sosyal yaşamın bir uzantısı olabilmektedir. Bu yüzden, insanın zihninde, 
sosyal yaşama ait tehdit oluşturan ögeler, Doğada, canavar benzeri hayvanlar, içinden çıkış yolu bulunamayan karanlık ormanlar, insan eti yiyen dev bitkiler kılığında, yani, Doğanın vahşice enerjilerini özetleyen tek sözcükle "şiddet" şeklinde imgelere dönüşmüştür. Bu çalışma, insanın insan-dışı varlıklarla ilişkisini, her bir canlı türünün, kendi özgün varlığını sürdürebilmesi için uygun koşullara sahip alanlarda yaşayabilmesine zemin hazırlayacak şekilde yeniden düzenleyebilmesinin yollarını sorgulamakta ve bu temel sorun üzerine düşünceleri incelemektedir.

Anahtar Kelimeler: Ekoeleştiri, Çevre Etiği, Modernizm, Postmodern Etik, Sami Paşazade Sezai

\title{
ENVIRONMENTAL ETHICS: “KEDİLER” BY SAMİ PAŞAZADE SEZAI
}

\begin{abstract}
Sami Paşazade Sezai, was an Ottoman author (1860 - 1936) who experienced the historical course of both the Ottoman and the Republican order. Sezai was considered to have attributed to the Western thought by his realistic short fiction that focused on usually ignored but bitter slight matters of social relations. His short story, Kediler (Cats - 1892), is one of his black-humour stories displaying man's stance in private life and man's relation to animals, especially to cats. What is aimed in this study is to discuss the recent orientations of environmental ethics, to add more to ecocriticism for establishing a clearly explicated base and view of life on earth. How do the current ethical codes manipulate man's attitude towards Nature, and the nonhuman? A really challenging task, it is, for man, to manage to organize an ethical code to structure human's renunciation of egoism and superiority complex and the ethical codes are at the base of the Postmodern approach, as a principle of criticism, interfering at those points where the Modernist Project comes to a deadlock. Man is prejudiced regarding Nature's meaning and power in the physical and spiritual sense. Nature has been subjected to a hierarchical dichotomy as opposed to culture. Moreover, the whole social-economical system has been established as based on those hierarchies which prioritises, discriminates and ranks all species and living entities on this planet. In this sense, Nature is considered by man, as an extension of the fragmented, subverted and marginalized cultural and social life. Thus, in man's mentality, those threats of the social life are disguised in forms of monstrous animals, dark forests with no way out, giant plants eating human flesh, simply, violence, to be depicted as Nature's wild energies. This study probes the ways of reorganizing man's relationship with the non-human, allowing every single living-entity suitable conditions according to its unique existence, in its domain of living.
\end{abstract}

\section{STRUCTURED ABSTRACT}

Exemplifying Sami Paşazade's short relistic story, "Kediler" (Cats), this study will question the conflicts and pursuits experienced in man's 
relationship to man and the non-human. Rather, the last phase that environmental ethics has reached and the recent orientations regarding the great ethical problematic will be discussed to display today's examinations and pursuits of environmental ethics, aiming to constitute a sound base for ecocriticism.

Environmental Ethics seeks responses to Nature and the nonhuman as a significantly effective part in human life. Man's response to Nature, the non-human directly determines the sustainability or else, the degeneration of the ecosystem. In this sense, the ecological conditions of any environment need to be fully equipped to exist healthily, providing equal opportunities for each entity suiting those specific needs of them to continue their survival. Man has been alienated from Nature, considering Nature monstrous, dark, unknown and mysterious. This has led man to try to be superior to Nature and dominate the non-human. So, "ecocriticism" submits to the field of environmental ethics a sound base involving real life stories and not to mention, a limitless imaginary range of creative work explicating the contradictory issues which require solutions. Theoretically, "ethics" as the prime (first) philosophy, discloses in its essence, the similar issues that environmental ethics displays. At this point, the interference of the postmodern ethical discussions highly contribute to the matter, clarifying the aspect of ethical relations among humans and and between humans and the non-human.

Sami Paşazade Sezai was born in 1860, in İstanbul. Being influenced by some Turkish autors such as Nam1k Kemal, Abdülhakhamit Tarhan, S. P. Sezai was prone to reject Divan Literature, seeking more liberated ways of writing. Inspired by the French author Alphonse Daudet, his short fiction was considered to be the primary realist work attributed to the Western thought. In his short fiction, S. P. Sezai focused on slight matters regarding social relations which were to be ignored but hurtful all the same. His short story, Kediler (cats) (1892), is one of those, including man's stance in private life and in his relationship to animals. Mixing the dramatically tragic aspects of life with a sense of humour, Sezai was prone to ridicule the ethical codes of social life, with a dose of humour that is one of the most effective weapons to criticize social relations. The author has ironically subverted the usual aspect of man's abuse of animals - Nature, in fact, and displayed man's being abused by animals; even by domestic animals, employing a dry-humoured style manipulating the whole of the story. The ecocritical view requires to make clear the blurred boundaries or, to express it in an other way, the contradictory domain of environmentalism involving global threats versus individual lives. The liberal conception of individual rights have had a long historical past rooted in the Enlightenment values of reason, rationalism, order and universalism. Reason and the rational way of thinking, as the pillars of the modernist project, establishes man's conception of "truth". Man needs to cling to Grand Narratives such as beliefs, ideologies and history which have been offering humanity an eventual hope - an eternal optimism - that at the next turn or next corner, wealth, prosperity and happiness will be "true" for every individual, as have been dreamt since the Renaissance and the Enlightenment and having extended through the modernist project. This corresponds to a longawaited future that man will be liberated from all institutional and 
natural pressures, reaching high levels of freedom and happiness. The paradoxical aspect related to man's inevitable need to cling to Grand Narratives is that those narratives are meant to liberate man by helping man to solve the vital ethical problems like sharing the limited resources, providing justice, freedom and founding democracy. On condition that man clings to them, Grand Narratives promise man an ostensibly bright future, appearing in the guise of reason, democracy and freedom of speech. Man, sooner or later confronts double binds in social life, rendering it almost impossible to make choices that will not harm any parties (sides). At this point of conflict, conventional moral and ethical codes can no more help man to abstain from violating the economical, political and ethical rights of any other party. Man feels trapped in the overwhelming impact of huge life problems, since $\mathrm{s} /$ he confronts serious obstacles regarding his/her capacity to distinguish right from wrong. Happiness collides with virtue; individual freedom collides with social freedom.

The postmodern thought and criticism interferes upon the "ambiquity" of ethical rules, which infact, had been constituted aiming at establishing order, justice and universalism. The "aporetic" essence of ethics in human relations has been directly manipulating man's relations with animals, plants, and the non-human, as a whole. In other words, "inequality" began with man's ascribing the top value to his/her mind, which led to the belief that man is superior to Nature - animals, plants, the non-living entities. In the work, titled, "Ethics Applied", within the chapter titled, "Ethics and Environment", it is embodied, "Animal bodies and plant organisms were more or less biological machines. So for four centuries, Western philosophy was dominantly humanistic or, to use a more recent term, anthropocentric (humancentered). People were what counted and all that counted in ethics" (Baker and Richardson,1999: 409). Environmental ethics that emerged in 1970's, expands the boundaries of ethics to involve Nature and requires Nature's sustainability to secure human wellbeing, as a response to various environmental problems which collectively make up today's environmental crisis. As Nigel Dower states in his work, Global Citizenship, two kinds of approaches underly "Environmentalism" which is protecting the environment: the natural world or the environment and non-human life do not have intrinsic value independent of us anda re there for human beings to use. This is "anthropocentrism", and Biocentrism: Non-human life has an intrinsic value independent of human interest, and therefore humans ought to respect Nature. (Dower, 2002: xx). Both philosophers and literary critics have found themselves dealing with the complex problematic issues regarding man's norms and values relating to the ways $\mathrm{s} /$ he interacts with her/his natural environment. Literature, as a matter of fact, provides ample materials in the sense of daily life experiences in the entire ecosphere. This study submits an ecocritical approach to environmental ethics to enlighten the problematic interaction between man and domesticable animals. Ecocriticism necessarily requires environmental ethics, to take a theoretically and practically well designed stance on the vast, complex issue of what relationship human beings should have to the natural world. The Ottoman author, Sami Passazade Sezai's short story, Kediler, presents a puzzling ambivalence in man's relationship to cats, which are the most widely domesticated 
animals. The questions, "What are the borders? "What are the ways of organizing an ethical code to structure humans' renunciation of egoism and superiority complex?" are insistently enforced. Those great wars, severe misery and annihilation that humanity has been experiencing, led to an aporetic state regarding the ethical codes that assume a vitally important role in leading the individual to make choices between the right and the wrong. The project of creating a universal ethical code has almost failed and paved the way to deep-seated hierarchical structures as binary oppositions - dichotomies, like nature/culture, masculine/feminine, rich / poor, strong/weak, etc. In the face of the great harm the planet Earth has been given, the relations between the hierarchical dichotomies need to be urgently reorganized, allowing each part to exist, maintaining what is "unique" and exceptional in her/his/its nature. Allowing each part (entity) to exist as enabled to flourish the unique qualities is the key to the expected reorganization of structures, since "reorganization" is not just the displacement of the strong; "reorganization" is securing the justice for each side so that all sides can get equal opportunities of living.

Keywords: Ecocriticism, Environmental Ethics, Modernist Project, Postmodern Ethics, Sami Paşazade Sezai

\section{Introduction}

Employing Sami Paşazade's short realistic story, "Kediler" (Cats), this study will question the conflicts and pursuits experienced in man's relationship to man and the non-human. Rather, the last phase that environmental ethics has reached and the recent orientations regarding the great ethical problematic will be discussed to display today's examinations and pursuits of environmental ethics, aiming to constitute a sound base for ecocriticism.

Environmental Ethics seeks responses to Nature and the non-human as a significantly effective part in human life. Man's response to Nature, the non-human directly determines the sustainability or else, the degeneration of the ecosystem. In this sense, the ecological conditions of any environment need to be fully equipped to exist healthily, providing equal opportunities for each entity suiting those specific needs of them to continue their survival. Man has been alienated from Nature, considering Nature monstrous, dark, unknown and mysterious. This has led man to try to be superior to Nature and dominate the non-human. So, "ecocriticism" submits to the field of environmental ethics a sound base involving real life stories and not to mention, a limitless imaginary range of creative work explicating the contradictory issues which require solutions. Theoretically, "ethics" as the prime (first) philosophy, discloses in its essence, the similar issues that environmental ethics displays. At this point, the interference of the postmodern ethical discussions highly contribute to the matter, clarifying the aspect of ethical relations among humans and and between humans and the non-human.

Sami Paşazade Sezai was born in 1860, in İstanbul. Being influenced by some Turkish autors such as Namık Kemal, Abdülhakhamit Tarhan, S. P. Sezai was prone to reject Divan Literature, seeking more liberated ways of writing. Inspired by the French author Alphonse Daudet, his short fiction was considered to be the primary realist work attributed to the Western thought. In his short fiction, S. P. Sezai focused on slight matters regarding social relations which were to be ignored but hurtful all the same. One of the writer's short stories, "İki Yüz Elli Kuruşa Bir Asır" (A Century for 250 cents) narrates how a nature lover's life is ruined because of logging. Nature, in Sezai's view, is not only an inspiring scenery, but a condition of man's existence. 
His short story, Kediler (cats) (1892), is one of those, including man's stance in private life and in his relationship to animals. Mixing the dramatically tragic aspects of life with a sense of humour, Sezai was prone to ridicule the ethical codes of social life, with a dose of humour that is one of the most effective weapons to criticize social relations. The author has ironically subverted the usual aspect of man's abuse of animals - Nature, in fact, and displayed man's being abused by animals; even by domestic animals, employing a dry-humoured style manipulating the whole of the story. Cats in the story have been the master and man is supposed to surrender to cats occupying man's environment. In the story, man's house stands for the sole private space belonging to man, which shows that Sezai combines masterfully, the "romantic" and the real life with a specific sense of living space (Törenek, 142-43).

The ecocritical view requires to make clear the blurred boundaries or, to express it in an other way, the contradictory domain of environmentalism involving global threats versus individual lives. The liberal conception of individual rights have had a long historical past rooted in the Enlightenment values of reason, rationalism, order and universalism. Reason and the rational way of thinking, as the pillars of the modernist project, establishes man's conception of "truth". Man needs to cling to Grand Narratives such as beliefs, ideologies and history which have been offering humanity an eventual hope - an eternal optimism - that at the next turn or next corner, wealth, prosperity and happiness will be "true" for every individual, as have been dreamt since the Renaissance and the Enlightenment and having extended through the modernist project. This corresponds to a long-awaited future that man will be liberated from all institutional and natural pressures, reaching high levels of freedom and happiness. The paradoxical aspect related to man's inevitable need to cling to Grand Narratives is that those narratives are meant to liberate man by helping man to solve the vital ethical problems like sharing the limited resources, providing justice, freedom and founding democracy. On condition that man clings to them, Grand Narratives promise man an ostensibly bright future, appearing in the guise of reason, democracy and freedom of speech. Man, sooner or later confronts double binds in social life, rendering it almost impossible to make choices that will not harm any parties (sides). At this point of conflict, conventional moral and ethical codes can no more help man to abstain from violating the economical, political and ethical rights of any other party. Man feels trapped in the overwhelming impact of huge life problems, since s/he confronts serious obstacles regarding his/her capacity to distinguish right from wrong. Happiness collides with virtue; individual freedom collides with social freedom.

The postmodern thought and criticism interferes upon the "ambiquity" of ethical rules, which infact, had been constituted aiming at establishing order, justice and universalism. The "aporetic" essence of ethics in human relations has been directly manipulating man's relations with animals, plants, and the non-human, as a whole. In other words, "inequality" began with man's ascribing the top value to his/her mind, which led to the belief that man is superior to Nature - animals, plants, the non-living entities. In the work, titled, "Ethics Applied", within the chapter titled, "Ethics and Environment", it is embodied, "Animal bodies and plant organisms were more or less biological machines. So for four centuries, Western philosophy was dominantly humanistic or, to use a more recent term, anthropocentric (human-centered). People were what counted and all that counted in ethics" (Baker and Richardson,1999: 409). Environmental ethics that emerged in 1970's, expands the boundaries of ethics to involve Nature and requires Nature's sustainability to secure human wellbeing, as a response to various environmental problems which collectively make up today's environmental crisis. As Nigel Dower states in his work, Global Citizenship, two kinds of approaches underly "Environmentalism" which is protecting the environment: the natural world or the environment and non-human life do not have intrinsic value independent of us anda re there for human beings to use. This is "anthropocentrism", and Biocentrism: Non-human life has an intrinsic value independent of human interest, and therefore humans ought to respect Nature. (Dower, 2002: xx). Both philosophers and literary critics have found themselves dealing with the complex problematic issues regarding 
man's norms and values relating to the ways s/he interacts with her/his natural environment. Literature, as a matter of fact, provides ample materials in the sense of daily life experiences in the entire ecosphere. This study submits an ecocritical approach to environmental ethics to enlighten the problematic interaction between man and domesticable animals. Ecocriticism necessarily requires environmental ethics, to take a theoretically and practically well designed stance on the vast, complex issue of what relationship human beings should have to the natural world. The Ottoman author, Sami Paşazade Sezai's short story, Kediler, presents a puzzling ambivalence in man's relationship to cats, which are the most widely domesticated animals. The questions, "What are the borders? "What are the ways of organizing an ethical code to structure humans' renunciation of egoism and superiority complex?" are insistently enforced. Those great wars, severe misery and annihilation that humanity has been experiencing, led to an aporetic state regarding the ethical codes that assume a vitally important role in leading the individual to make choices between the right and the wrong. The project of creating a universal ethical code has almost failed and paved the way to deep-seated hierarchical structures as binary oppositions - dichotomies, like nature/culture, masculine/feminine, rich /poor, strong/weak, etc. In the face of the great harm the planet Earth has been given, the relations between the hierarchical dichotomies need to be urgently reorganized, allowing each part to exist, maintaining what is "unique" and exceptional in her/his/its nature. Allowing each part (entity) to exist as enabled to flourish the unique qualities is the key to the expected reorganization of structures, since "reorganization" is not just the displacement of the strong; "reorganization" is securing the justice for each side so that all sides can get equal opportunities of living and the system encourages not the stronger, but the righteous.

\section{Sami Paşazade Sezai}

Sami Paşazade Sezai's work is known to have introduced the modern Turkish short fiction to Ottoman culture and literature. Inspite of Sezai's being influenced by some famous Turkish authors like Namık Kemal, Abdülhak Hamit Tarhan, the author pursued an entirely distinct way, admiring the French author, Alphonse Daudet's fiction and style and abandoning the style of Divan literature that foregrounded poetic language, rather than prose. Sezai's prose aimed at excluding the traditional, restrictive details imposed by the poetic view and including a simple narration of usual life aspects, as adopted by the French and Western authors, in general.

Sezai intended to display within social relations, those slight matters which seemed not to deserve any consideration but which were, and are always as hurtful as stab wound. Sezai managed to add a dose of humour to the dramatical aspects of daily life, to justify that life is as beautiful as it is painful. The author's short story, Kediler (Sezai, 1892), presents a humorous view related to man's relationship to man and the non-human. The story urges some significant questions like, "In what way should human beings' relationship with animals be organized? What ethical code can organize it in the best possible way? How can humans' ego and superiority complex be structured?" In the story, the main conflict is put forward as determining the borders of human and non-human relationship.

\section{Kediler (Cats)}

Usually human beings cause animal suffering but Sezai's character is a husband exposed to the superiority of animals (Sezai, 2016). He is suffering from cats; too many cats occupying his house, his only private domain. Cats were at every corner in his house; wondering with their tails up, with noses in the air, sitting on his sofa and chairs, lying on soft cushions by the hot stove, always taking up the best comfortable places. Moreover, they would drink his coffee, eat his meal, always at rest and upto some mischief. Once he fell down the stairs while he was trying to hit a white cat that had drunk his coffee. His wife came down on him, saying, "How could you hit this animal like that? What if her leg was broken?" That was the last straw; the husband left the house slamming the door. Whenever he complained to his wife about his wife's overindulging in cats, she would say, "You should be glad that I love them! What if I loved to flirt with men?" So, he asked his wife to make a choice between 
himself and cats. The answer was, "Absolutely, cats". Upon this answer, he felt that it was a marital breakdown; the breakdown of his marriage of thirty-three years. Now he was alone. Not knowing where to go, he was taking an other road whenever he saw a cat in the streets. Time flawed too slow. He felt desperate. He was hungry, he needed the comfort of home. "Go to your harem, go to her," said his inner voice. He had to return to his house which he had left with fury just in the morning, as if he would never return there again. He entered into the house without looking at or saying anything to his wife. He went upstairs to the bedroom, buried his face into the cushion and cried his heart out. Upon hearing his sobbing, his wife kindly opened the door and said, "Do not cry screaming this way! You will freighten my cats!" This utterence proved that his wife considered him a man of straw; cats were much more worthful. Cats held the power in his house; he, as a man, as a husband, was a lay figure in his own house.

\section{Ecocritical View}

From an ecocritical point of view, man's relationship with the non-human constitutes a significant part of human culture. The non-human are not just objects; they build up many aspects within the meaning attributed to life by humans. Alan Liu, in his work, "Wordsworth, The Sense of History", embodies that "nature is the name under which we use the non-human to validate the human, to interpose a mediation able to make humanity more easy with itself (Liu, 1989: 38). Humans socially construct notions of nature; they relate various references to nature; cultural assumptions of politics, ideology and beliefs, that is to say, 'grand narratives' which have been actively creating the codes of comprehending life and what's going on in this planet.

The ecocritical view requires to make clear the blurred boundaries or, to express it in an other way, the contradictory domain of environmentalism as nature involves global threats versus individual lives. The liberal conception of individual rights have had a long historical past rooted in the Enlightenment values of reason, rationalism, order and universalism. Reason and the rational way of thinking, as the pillars of the modernist project, establishes man's conception of "truth". Man needs to cling to 'grand narratives' such as beliefs, ideologies and history which have been offering humanity an eventual hope - an eternal optimism - that at the next turn or next corner, wealth, prosperity and happiness will be "true" for every individual, as have been dreamt since the Renaissance and the Enlightenment, having extended through the modernist project. This corresponds to the future that man will be liberated from all institutional and natural pressures.

The paradoxical aspect related to man's inevitable need to cling to Grand Narratives is that those narratives are meant to liberate man by helping man to solve the vital ethical problems like sharing the limited resources, providing justice, freedom and founding democracy. However, man, sooner or later confronts double binds that render it almost impossible to make choices that will not harm any of the concerned parties (sides). At this conflict, conventional moral and ethical codes can no more help man to abstain from violating the economical, political and ethical rights of any other party. The postmodern thought and criticism interferes upon the "ambiquity" of ethical rules, which infact, had been constituted aiming at establishing order, justice and universalism.

\section{Modernism and Ethics}

Modern society has till today been aware that universalism - the establishable objective truth is subject to an 'aporetic situation'; humanity and /or individuals have to face unresolvable conflicts which leave them so helpless that they do not even have a chance of making a choice; they are forced to do this or that which results in self-renunciation. Self renunciation might correspond to suffering because of depletion of social, economic rights and freedoms. The harmony that is awaited at the end of each effort, each feat of reason, has been unable to make it and on the contrary, has caused new wounds; new incurable wounds - more cruelty and less morality. Zygmunt Bauman asserts that in fact, humans are morally ambigous and ambiquity exists in the essence of a face-to-face human 
relation. "Given the primary structure of human togetherness, a non-ambiguous morality is an existential impossibility. No logically coherent ethical code can 'fit' the essentially ambigous condition of morality" (Bauman, 1993:10).

Modernist project has designed a pattern of Law - rules and order - to define the "proper" and "improper" actions. The designation of those laws and rules indicates that the individual is supposed to learn the knowledge of laws and rules, which will lead to turning over one's personal autonomy into a power-supported heteronomy. Acting in accordance with laws, rules and regulations requires "reason" and this justifies that the individual will that submits to certain principles of laws, corresponds to reason.

To express the ethically organized relation of the individual as a social being, more explicitly, it has to be emphasized that the "self" is primarily in a moral context; the "self" is in nature, a "moralself" which, as remarked by the French philosopher, Emmanuel Lévinas, experiences an unsymmetrical relation, while being FOR the Other, rather than being 'with' the Other. "I am for the Other whether the Other is for me or not; his being for me is, so to speak, his problem and whether or how he handles that problem does not in the least effect my being for Him... My relation to the Other is not reversible... In a moral relationship, all the duties and rules that may be conceived are addressed solely to me, bind only me, constitute me and me alone as an "I"..." (Bauman, 1993:50). As a result, "I am ready to die FOR the Other " is a moral statement; "He should be ready to die FOR me" is absolutely, not.

The above discussions of ethics aim at scrutinizing the ways of creating a sound base for ethical codes which determine behaviours and actions through human relations - I and the Other. Behaviours and actions build up meanings that manipulate social life; meanings actually constitute the "truth" adopted by a human community. The recent developments in human life demonstrate that despite its long historical past, the rational establishment of social life, in other words, the absolutism of reason has not been able to prevent great wars, annihilation, oppression and violence on the planet, Earth. Emmanuel Lévinas' account of the Other creates an entirely novel base for the relation with the Other in the sense that the properties of the Other as unique and exceptional are erased, the Other is no more marginalized, no more rendered as the weak side within the hierarchies and is reduced to reciprocity, compatibility and mutuality. Thus, Lévinas' aspect of the relationship with the Other opens the way to the unthought and the unspoken within the borders of a closed and centrally fixed system which encourages hierarchies, oppression and isolation of the Other.

\section{Emmanuel Levinas and Jacques Derrida}

As did E. Lévinas, so did the French philosopher Jacques Derrida attempt to render the Other 'free" by eliminating the hierarchical system of 'binary oppositions'. The Derridean account of deconstruction as an "openness towards the other" reinforces and goes along with Emmanuel Levinas' account of the other. The term, "deconstruction" was first employed by Derrida in his work, Of Grammatology, in which he examines the interaction between language and the construction of meaning. By displacing Ferdinand de Saussure's view of the signifier-signified relation, regarding the arbitrary relation between the signifier and the signified, Derrida embodies that the signifier is placed within a domain of unending -eternal- interactions of signs. The reason for this assumption is that no priority or hierarchy can explain the relation between the signifier and the signified: This doesn't by simple inversion mean that the signifier is fundamental or primary. The "primacy" or "priority" of the signifier would be an expression untenably absurd to formulate illogically within the very logic that it would legitimately destroy. The signifier will never by rights precede the signified, in which case it would no longer be a signifier and the signifying signifier would no longer have a possible signified (Derrida, 1997:234). 
The basic idea in Derrida's view is that any institutionalization, any authoritative definition corresponds to a thought system bearing an inherent desire to have a centre, or a focal point, conceptionalized as "logocentrism" by Derrida. The "centre" that is assumed to be the origin, has been claimed by a hegemony that encourages stability within the structures of truth, meaning, authority that paves the way for the monopoly of discourse, knowledge and power. Truth, knowledge and power, as organized by a coherent center, explicated by Michel Foucault, as well, in the sense that Foucault " Articulates an unquestionable suspicion toward any order through which knowledge is transformed into power and vice versa" (Foucault, 1988: 15ii), is the crucial point displaying Derrida's deconstructive aim. Derrida underlines that all systems of thought are forming a locked-up structure within the voice of "margins", that is, traditionally, the unthought, unspoken and unpresentable. The strictly determined limits of closed systems render the communities being socialized according to those systems blind to the dogmatism that causes violent practices especially making it impossible for the Other to speak and let his/her voice be heard. This explicates in what way modernism has been developing a capacity of resisting to self-scrutinization and self-criticism; modernism, by attaining unachievable targets, has covered its mechanizations of reproduction with a veil of illusions.

The required critical insight into illusions of closed systems might be formed throughout deconstruction of 'presence' in reading centre-fixed (logocentric) texts. The meaning is reduced in writing and since the 'fragmented reality' is always already in language itself, conflicting readings of a text can be realized so that the idea of "the true original meaning" is questioned. Thus, difference and deferral -différance- is inherent in language itself, displaying the play of language within each word. To Derrida, there is no privileged signified, for the domain of meaning and play of movement have no constraints and the very moment " the sign" is expressed, it has to be denied as a concept and a word (Derrida, 1978:354).

E. Levinas, J. Derrida and many philosophers, since the ancient ages, have been attempting to find ways of establishing justice and equality in exercising basic rights that every man deserves by birth. The whole Western civilization is actually, a narrative of the historically shaped grand narratives - beliefs, conceptions, ideologies, etc. Finally, the arguments mankind now turns to, is that the closed systems of thought which these grand narratives present, have been resulting in violent and destructive practices, calling into action all evil-ghosts to transform humans into a gear-wheel of techno-capitalist system manipulated by dominant conceptions of meanings and knowledge..

Today, a great portion of human beings faces serious deprivations despite the advanced level of technology maintaining mass-consumption and mass-communication. Emergency threats suggest that violence and destruction are intermingled with the planet, Earth's, environmental annihilation. The great anxiety of the era is to manage to distinguish what is natural and what is not. "Nature is no longer "natural", the reliable "dense" background of our lives; it now appears as a fragile mechanism, which, at any point, can explode in a catastrophic manner" (Zizek, 2008:435). In a critical sense, the stable categorization of the human and the nonhuman requires the urgent challenge of philosophers, academicians, and mostly the political figures assigned to hold the power in the name of people. The hierarchical structures, the assimilation of the weak and vulnerable party, the manipulation and owning of the nonhuman still await to be freed from the devilish impact that the anthropocentric ego and superiority maintain with all their might.

"The moral impetus behind ecocriticism, necessarily commits it to take some kind of stance, however implicit, on th huge issue of what relationship humanbeings should have to the natural world" (Clark, 2011: 5). Ecocriticism brings together the ethical problematic of humanity as the primary philosophy and the environmental no-way-out situation of the planet, Earth. The problematic rests on a common ground: ethics as the base of human socialization, involves the deal of unequal hierarchical relation of the human with the nonhuman. Those pet animals humans own and take care of at home are the most innocent of the ecological, nature-friendly stance displayed by humans. Cats are the ones 
most widely domesticated, alongside dogs, hamsters, birds, fish and rabbits. The literary signification of cats is more widely employed than any other animal. It might be because cats are the most selfaggrandising animals versus the arrogance of humans. As possessively dominant, patronizing animals, cats have been subject to images of devil, witch, evil and sinister creatures. Cats are not useful figures like dogs who are at least expected to protect home and family that own them. The image of cats has been popularized throughout cartoons, films and jokes within cultural tradition.

As an early and striking example of literary aspect, Sami Paşazade Sezai's short story, "Kediler", introduces a husband's dramatic and desperate situation, that is, his house, his most private domain, being occupied by a number of cats loved more than him by his wife. A human's suffering is ironically caused by animals; the very fact implicates human beings' fear against nature's undefeatable power. Theoretically, those who defend "Weak Animal Rights Theory", do not feel like drawing a line between those animals that are equally valued to humans and those that have no value at all. It is significant to note that in all religions as Judaism, Islam and Christianity, "Weak Animal Rights Theory" corresponds to the fact that despite the highest value is ascribed to human beings, all animals, as well, deserve the least value and moral consideration.

As for "ecocentrism", not only individuals but the whole ecosystem requires to be kept in harmony, stabilty, integrity, as Aldo Leopold stated in his, "Sand County Almanac". "Deep ecologists" are maybe the most radical representers of the matter; deep ecology asserts, "The lifestyle of persons in affluent nations must be dramatically changed and the human population of the Earth should be greatly reduced. They are critical of globalization, as well, arguing for decentrilization for political and economic spheres and for increased respect for cultural diversity" (Derr, Mcnamara, 2003:xix).

As considered above, arguments regarding environmental ethics arrive at the problematic of organizing a mutually "just" ethical relation, by eliminating hierarchies and marginalization. Philosophers have been struggling to question "rights doctrine" of the Western tradition and have found it " as hierarchical because of binary oppositions, dualistic because of its distinctions between humans and nonhumans, atomistic because it portrays humans as isolated units, and abstract because conflicts about rights are settled by rationalistic impersonal debates that ignore both feelings and the particular needs/traits of the individuals involved "(Zimmerman, 1994:241). Emmanuel Levinas has emphasized the self's primary moral context that renders it a "moral self". Jacques Derrida's key concept, deconstruction interrogates the relationship between rules, practices and justice. The centrally controlled and manipulated systems make the way for hierarchical relations as well as the domination of the strong over the weak and the vulnerable. Deconstruction shows that there are many ways of comprehending the truth; truth does not rely on an absolute interpretation.

\section{Conclusion}

Sami Paşazade Sezai's short story, Kediler (Cats), has been constructed from not a consciously but a spontaneously ecological view, challenging the anthropocentrical establishment of beliefs, notions, and mentalities of mankind, as regards to survival and existence on Earth. Towards the end of the 19th century, in the year 1892, when "ecology" or "ecological degradation" was unmentioned and nature and natural resources were not ruined at all, as they are, today, literature was the sole field to emphasize the significance of Human - Nature - Non-human relationship; many authors felt themselves in charge of expressing in the best way, the great role of Nature that can not be underrated, in man's life. Owing to the work of thes authors, various scientific approaches of today, can challenge the borders of already existing theoretical perceptions.

The story, Kediler, exemplifies an unusual human - non-human relationship describing cats' domination over a man who is repressed and rendered unauthorized within his family and his own house. Cats are in every corner of his house, drinking his coffee, sitting in his arm chair and sleeping 
in his bed. Furthermore, his wife's unadulterated devotion to cats would double his situation as a loser. His wife is absolutely on the side of cats; the story ends displaying the poor husband's tears and his wife's warning him to stop making noise of cries and not disturb the cats.

In what way should the "ethical codes" be designed so that no man and no non-human member of this planet might be suffering from violations of others? "Ethics" is the first philosophy, "ethical codes" construct the entire "truth" that is embeded in human life. Nevertheless, organizing the ethical codes is the most speculative act that is at the base of all human problems.

The Enlightenment values such as reason, rationalism, order and universalism have helped humanity to overcome blind obediences to obsessive and dogmatic beliefs of middle ages and paved the way for novelties in technology, art and culture as a whole. Science has made a great progress as rationalism speeded the scientific studies relying on the objective truth. The system at the center of which, is the individual, has rendered the individual self-directed in thought and action through the awakening of one's intellectual powers. Man has constituted the "truth" as is embodied in ideologies, beliefs, histories and metaphors - "grand narratives", actually -. The common aspect or the problematic emphasized in all grand narratives rests on organizing man's relationship to both man and the non-human in the best way possible. The key discipline is "ethics", as the first philosophy for humans' life on earth.

The French philosopher, Emmanuel Levinas has made entirely novel contributions to the ethical problematic, basically the relationship between "I" and "the Other". As is acknowledged by Zygmunt Bauman, the Polish philosopher and the sociologist, as well, Levinas emphasizes the unsymmetrical relation between "I" and "the Other". "I am for the Other whether the Other is for me or not; my relation to the Other is not reversible. A moral relationship assumes on me; only on me, certain duties, responsibilities and rules which bind me alone as an "I"." So, "I am ready to die for the Other" is a moral statement, whereas, "He should be ready to die for me" is by no means, a moral statement.

Levinas and Bauman have explicated the sociological aspect of the "I" and "the Other" relationship, while the French philosopher Jacques Derrida has elucidated the matter in the context of language and the construction of meaning. To Derrida, no priority or hierarchy can explain the relation between the signifier and the signified: the "logocentrism" that encourages the dependence upon the origin, provides stability in the truth; in other words, in meaning. However, being organized in coherence to the center, as claims Michel Foucault, too, causes the hegemony and the monopoly of discourse, knowledge, and power. The Foucauldian aspect no doubt, echoes with the Derridian aspect in that both aspects aim at eliminating the priority or the superiority of the signifier over the signified, the hierarchical social relations, opening the way to deconstruction of established structures, to expose that there are still other ways of structuring the truths.

Ecocriticism presents a critical approach to the hierarchical organization of man's relation to man, to nature and the non-human. Challenging man's superiority complex that misguides man regarding his being at the center of all living and non-living things, the ecocritical approach seems to stand alongside the postmodern ethical view and the deconstructional aspect. Ecocriticism contributes, in this sense, a lot to man's conception of "moral self", though this common point is reached throughout a rightminded anxiety of the planet's destruction. The common fact is that all arguments are for the establishment of justice and a non-discriminatory sharing of the existing resources, the precondition of which is struggling for the sustainability of those resources.

Ecocriticism takes the advantage of tracing those arguments of setting the justice, providing the sustainability of the resources, throughout literature, presenting vivid examples extending along real life. "Kediler" by Samipaşazade Sezai is one of those literary texts, displaying a sound voice to consider the conflict experienced by man in his relationship to the human, the non-human and Nature. 
As exemplified by Sezai's short story, "Kediler", Nature's manipulation needs knowing and comprehending the needs of various living things which constitute Nature. Man has to stop violating the environment of animals, plants, even of his own. Those cats in the story need to be provided a more natural setting either within the house or outdoor; taking care of more than one cat requires to handle their health and habitat more professionally.

The victimization of the husband in the story is not caused by cats, or in other words, "Nature", but by the negligent and imperfect caring ways of the wife. Likewise, man's eradicating forests and building residences as an extension of urban complex, is a negligent way of organizing the urban living quarters. Mankind should create new narratives in which all living and non-living things are allowed rights of healthy biological and physical existence. Each animal or living and non-living entity requires its private - unharmed domain where it can survive within the most convenient physical and biological conditions. Any insensible and ignorant interference to the private domain of living and non-living entities would possibly cause a deterioration and corruption within the environment of animals, plants, and even rocks and stones.

As regards the short story, "Kediler", in the year 1892, there used to be no vaccination, no flea collars for pets. Although cats, alongside dogs, lovebirds and parrots, are the most domestic animals, they should be taken care of taking precautions for both their and the family members'health. There are some parasites of droppings and animal fur that can affect man if cats and dogs are not vaccinated. Since the wife in the story seems to care nothing about health, she is absolutely ignorant about animal husbandary. Cats drink the husband's milk, cats sit in the husband's armchair and lie in his bed. The husband does not maintain any hatred against animals; the most significant problem for him is his wife's indifference to him. The writer, Sami Paşazade Sezai has depicted the violated environment of both cats and man with a great sense of humour, subverting the usual sign-signified relationship and paving the way for considering the matters of justice and sustainability from an entirely different angle.

\section{KAYNAKÇA}

Bauman, Zygmunt (1993) Postmodern Ethics, Blackwell Publishing, Malden, MA, USA, 10.

Baker, Emily, Richardson, Michael, eds., (1999) Ethics Applied, Edition 2, Simon and Schuster, New York, 409.

Clark, Timothy (2011) The Cambridge Introduction to Literature and the Environment, Cambridge University Press, USA, 5.

Derrida, Jacques (1997) Of Grammatology, Johns Hopkins University, Baltimore and London, 234.

Derrida, Jacques (1978) Writing and Difference, Routledge Classics, trans. Alan Boss, London, 354.

Derr, Patrick, G., Mcnamara, M., Edward, (2003) Case Studies in Environmental Ethics, Rowman \& Littlefield Publishers, Inc., Maryland, USA, xix.

Dower, Nigel, (2002) Global Citizenship, Routledge, New York, xx.

Foucault, Michel (1988) Politics, Philosophy, Culture: Interviews and Other Writings, 1977-1984, ed., Introduction, 15ii.

Liu, Alan (1989) Wordsworth, The Sense of History, Stanford University Press, CA, 38.

Sezai, SamiPaşazade, (2016) Küçük Şeyler: Kediler, Edt. Osman Sevim, Bilge Kültür Sanat, İstanbul, 47-61. 


Törenek, Mehmet, Hikâyeciliğimize Düşen Cemre: Küçük Şeyler,
http://www.turkiyatjournal.com/Makaleler/982351136_11.pdf, 142-43.

Zimmerman, Michael, E., (1994) Contesting Earth's Future: Radical Ecology and Postmodernity, Berkeley, University of California Press, 241.

Zizek, Slavoj, (2008) In defence of Lost Causes, Verso, London, 435. 